\title{
PENGARUH KOMPETENSI SUMBER DAYA MANUSIA TERHADAP PENERAPAN AKUNTANSI AKRUAL DENGAN PERANGKAT PENDUKUNG SEBAGAI VARIABEL MODERATING (STUDI EMPIRIS PADA PEMERINTAH KOTA YOGYAKARTA)
}

\author{
Dwi Sudaryati \\ Sucahyo Heriningsih \\ UPN Veteran Yogyakarta \\ e-mail : sudaryati_dwi@yahoo.com
}

\begin{abstract}
This study aims to empirically examine the effect of human resource competencies to the successful implementation of accrual accounting (PP 71 of 2010) with the support device as a moderating variable in the Local Government of Yogyakarta city. The population in this study was a head on education and KDP staff sectors in the local government area of the city of Yogyakarta is involved in the process of preparation of the financial statements. Sampling technique using simple random sampling and testing hypotheses using multiple regression analysis (multiple regression). The results of this study prove that the human resource competencies significantly influence the successful implementation of Accrual Accounting (PP 71 of 2010). However, the competence of human resources associated with the device does not support a significant effect on the successful implementation of Accrual Accounting (PP 71 of 2010). The result is expected, can assist policy makers in understanding the factors that support the successful implementation of accrual accounting rate (PP 71 In 2010, the Government Accounting Standards berbasil full acrual).
\end{abstract}

Keywords: implementation of accrual accounting, human resource competencies, supporting devices

\footnotetext{
PENDAHULUAN

Penyusunan laporan keuangan merupakan suatu bentuk kebutuhan adanya sistem transparansi yang merupakan syarat pendukung dari akuntabilitas yang berupa keterbukaan pemerintah atas aktivitas pengelolaan sumber daya publik. Pada dasarnya semua peraturan tersebut untuk tercapainya sistem transparansi dan akuntabilitas dalam pengelolaan keuangan daerah. Dengan kedinamisan akan kebutuhan atas standar akuntansi pemerintah, untuk mewujudkan
}

penyelenggaraan pemerintahan yang transparan dan akuntabel dalam pengelolaan keuangan Negara, maka perlu adanya sistem pencatatan yang menjamin bahwa segala informasi atau peristiwa penting yang terjadi di pemerintahan terekam dengan baik dengan ukuran-ukuran yang jelas dan dapat nilai melalui proses akuntansi ke dalam bentuk laporan keuangan. Dengan laporan keuangan semua informasi yang dibutuhkan oleh berbagai pihak baik sebagai rakyat, penanam modal, para anggota legislatif maupun kreditur akan dapat terakomodasi secara komprehensif. 
Kendala utama seringkali terjadi karena sudah terbiasanya SDM dengan sistem pencataan keuangan yang selama ini (lebih dari 50 th pemerintahan Indonesia) menggunakan single entry, sehingga untuk merubah menjadi double entry menjadi sangat sulit. Berdasarkan survey awal masih banyak pemda-pemda yang belum menerapkan PP No 24 tahun 2005 sesuai dengan yang ditetapkan, hal ini mengindikasikan masih rendahnya SDM yang dimiliki Pemda dalam mengiplementasikan peraturan tersebut dan mungkin terjadi karena kurang di dukungnya perangkat pendukung yang dimiliki Pemerintah serta masih rendahnya komitmen Pemerintah dalam penerapan Standar Akuntansi Pemerintah kas menuju akrual. Oleh karena itu diperlukan komitmen Pemda dalam menyiapkan SDM maupun perangkat pendukung agar tercapainya perubahan dalam sistem pencatatan akuntansi pemerintah berbasis full accrual. (Oluseyi O., 2010).

Menurut penelitian Sulani (2009) Kabupaten Labuhan Batu bahwa keberhasilan penerapan PP no 24 tahun 2005 sangat di dukung oleh kompetensi SDM maupun perangkat pendukung. Kompetensi SDM yang baik membutuhkan perangkat pendukung yang baik pula, sehingga penerapan akuntansi akrual akan semakin berhasil. Dengan berubahnya PP no.24 tahun 2005 (SAP berdasarkan Kas menuju akrual) menjadi PP No 71 th 2010 (SAP berbasis full accrual) maka dalam penelitian ini ingin menguji penerapan akuntansi akrual dengan obyek di Pemda Kota Yogyakarta. Pemda Kota Yogyakarta memiliki indeks korupsi tinggi artinya pemda tersebut bersih dari korupsi. Selain itu, Pemda Kota Yogyakarta selama 3 tahun berturut-turut mendapatkan opini auditor WTP (tahun 2010, 2011 dan 2012).

Berdasarkan latar belakang masalah tersebut, penelitian ini bertujuan untuk menguji pengaruh sumberdaya manusia terhadap keberhasilan penerapan akuntansi akrual (PP
No.71 tahun 2010) dengan perangkat pendukung sebagai variabel moderasi pada Pemerintah Daerah Kota Yogyakarta.

\section{REVIEW LITERATUR DAN HIPOTESIS}

Laporan keuangan pemerintah sebagai salah satuperwujudan sistem pertanggungjawaban pemerintah atas penggunaan keuangan daerah, dalam kerangka pelaksanaan otonomi daerah. Laporan keuangan merupakan hasil dari proses akuntansi yang berisi informasi keuangan. Informasi keuangan yang terdapat dalam laporan keuangan tersebut digunakan oleh pihak-pihak yang berkepentingan. Baik pihak internal maupun pihak eksternal. Adanya tuntutan yang semakin besar terhadap akuntabilitas publik, menimbulkan implikasi bagi manajemen sektor publik untuk memberikan informasi kepada publik.

Peraturan Pemerintah No. 71 Tahun 2010 berisi Standar Akuntansi Pemerintah (SAP) berbasis akrual. SAP ini mengakui pendapatan, beban, asset, utang dan ekuitas dalam pelaporan keuangan berbasis akrual. Sedangkan pengakuan pendapatan, belanja dan pembiayaan dalam pelaporan pelaksanaan anggaran berdasarkan basis yang di tetapkan APBN/APBD. Laporan keuangan yang dihasilkan dalam SAP ini adalah LAporan Realisasi Anggaran (LRA), neraca, laporan arus kas, catatan atas laporan keuangan, laporan operasional, laporan perubahan SAL(Saldo Anggaran Lebih) dan laporan perubahan ekuitas.

Kualitas sumber daya manusia dapat di ukur dari kemampuan pengetahuannya (knowledge) dalam arti semakin memahami/ berpengetahuan maka semakin luas wawasan SDM yang tercermin dalam kinerjanya yang kompeten, cepat dan inovatif dalam mempelajari peraturan baru (Oluseyi O, 2010). Nilai dari sumberdaya manusia sebetulnya merupakan jumlah nilai dari suatu organisasi yang dapat di sebut sebagai Modal intelektual yang terdiri 
dari orang-orang dalam organisasi, kemampuan yang mereka miliki, dan menggunakanya dalam pekerjaan mereka. Dan jika ini terjadi di pemerintahan maka jika pemerintahan memiliki SDM yang berkualitas maka akan menjadikan daerah tersebut menjadi daerah yang makmur. Kesuksesan pemerintah akan menjadikan perekonomian suatu negara menjadi lebih baik. (Kuratko dan Hodgest, 1997).

Perangkat pendukung dalam suatu organisasi mempunyai peran yang sangat penting dengan munculnya standart akuntansi pemerintah dengan basis akrual. Karena dengan basis akrual berarti diperlukan perangkat lunak (software) yang mendukung pencatatan dengan double entry, sehingga teknologi informasi menjadi suatu kebutuhan untuk mendukung kesuksesan penerapan standar akuntansi pemerintah berbasis full acrual. Hal ini dapat dilihat dari banyaknya aplikasi program yang ditawarkan untuk mempermudah dalam membuat laporan keuangan dan mempermudah SKPD dalam menyiapkan laporan keuangan sesuai SAP dan dengan penggunaan perangkat pendukung yang optimal (Sulani, 2009).

Hasil penelitian Azhar (2007) menyatakan bahwa terdapat pengaruh sumberdaya manusia dan perangkat pendukungnya terhadap keberhasilan penerapan permendagri 13 pada pemerintah Kota Langsa. Sulani (2009), hasil penelitiannya menunjukkan bahwa sumberdaya manusia dan perangkat pendukungnya mampu menjelaskan keberhasilan penerapan peraturan pemerintah No.24 Tahun 2005 tetapi tidak signifikan. Sedangkan komitmen memiliki pengaruh yang positif dan signifikan terhadap keberhasilan penerapan peraturan pemerintah No.24 Tahun 2005. Oluseyi O. (2010) dalam penelitiannya yang membandingkan pelaksanaan akuntansi akrual di Inggris dengan New Zeland, menyatakan bahwa peran sumber daya manusia, terutama para birokrat sangat penting perannya dalam meningkatkan tercapai mewujudkan tata kelola yang baik dan meningkatnya professionalisme para akuntan pemerintah sehingga dapat mendukung penerapan akuntansi akrual.

Dari penjelasan latar belakang masalah dan berdasarkan hasil penelitian terdahulu maka hipotesis penilitian ini sebagai berikut:

H1: Kompetensi sumberdaya manusia berpengaruh terhadap keberhasilan penerapan Akuntansi Akrual (PP No.71 Tahun 2010)

$\mathrm{H} 2$ : Kompetensi sumberdaya manusia yang berhubungan dengan perangkat pendukung berpengaruh terhadap keberhasilan penerapan Akuntansi Akrual (PP No.71 Tahun 2010)

\section{METODE PENELITIAN}

Penelitianiniakan dilakukandipemerintah daerah kota Yogyakarta, dengan mengunakan data primer dengan mengirimkan kuisioner kepada kepala SKPD dan staf PPK SKPD di wilayah Pemerintah daerah Kota Yogyakarta yang terlibat dalam proses penyusunan laporan keuangan daerah. Populasi dalam penelitian ini adalah kepala SKPD dan staf PPK SKPD di wilayah Pemerintah daerah Kota Yogyakarta yang terlibat dalam proses penyusunan laporan keuangan daerah. Teknik pengambilan sampel menggunakan simple random sampling. Berikut ini adalah definisi operasional variable yang terdapat dalam penelitian ini:

1. Penerapan akuntansi akrual (PP No.71 tahun 2010)

Keberhasilan penerapan PP No.71 Tahun 2010 adalah kemampuan dari masing SKPD dalam menyusun laporan keuangan semester 1 dan semester 2 sesuai dengan standart, tepat waktu, dan tidak menggunakan jasa konsultan. Variabel dependen ini diukur dengan berdasarkan persepsi dari responden tentang keberhasilan mereka menerapkan peraturan baru, dengan menggunakan skala likert 1 ( sangat tidak setuju) sampai dengan 
5 (sangat setuju), dengan skala interval. (Sulani, 2009).

2. Kompetensi sumberdaya manusia

Sumber daya manusia adalah kemampuan dari anggota PPK SKPD dalam melaksanakan tugasnya dalam hal penyusunan laporan keuangan SKPD. (Oluseyi O. 2010). Kompetensi sumber daya manusia (variabel independen) di ukur berdasarkan persepsi responden tentang kemampuan mereka dalam melaksanakan tugas yang diberikan. Variabel ini diukur dengan skala likert 1 ( sangat tidak setuju) sampai dengan 5 (sangat setuju).

3. Perangkat Pendukung

Perangkat pendukung adalah ketersediaan perangkat pendukung yang akan membantu sumber daya manusia dalam melaksanakan tugas seperti tersedianya komputer dan software yang berkaitan dengan kebutuhan dalam membantu penyusunan laporan keuangan pemerintah daerah. Perangkat pendukung (variabel independen) diukur dengan skala likert 1 (sangat tidak setuju) sampai dengan 5 (sangat setuju), dengan skala interval (Sulani, 2009).

Untuk menguji hipotesis yang diajukan, peneliti menggunakan 2 (dua) model persamaan regresi sebagai berikut:

$$
\begin{aligned}
& \mathrm{PP}=\beta_{0}+\beta_{1} \mathrm{SDM}+\mathrm{e} \ldots \ldots \ldots \ldots \ldots \ldots \ldots \\
& \mathrm{PP}=\beta_{0}+\beta_{1} \mathrm{SDM}+\beta_{2} \mathrm{P}+\beta_{3} \mathrm{SDM} * \mathrm{P}+\mathrm{e} . .
\end{aligned}
$$

Keterangan :

$\mathrm{PP}=$ Persepsi tentang keberhasilan penerapan akuntansi akrual

$\mathrm{SDM}=$ Kompetensi sumberdaya manusia $\mathrm{P}=$ Perangkat pendukung

\section{HASIL PENELITIAN DAN PEMBAHASAN}

\section{Deskriptif Penelitian}

Berdasarkan data yang diperoleh dari Pemerintah Kota Yogyakarta bahwa terdapat 32
SKPD yang terdiri atas Sekretariat Daerah, Dinas dan Lembaga Teknis. Data dalam penelitian ini dikumpulkan dengan menyebarkan kuesioner kepada responden di kantor, dinas, badan, sekretariat daerah dan sekretariat DPRD di Kota Yogyakarta. Kuesioner disebarkan dengan cara mengantar langsung kepada responden. Kuesioner ditinggal kemudian diambil kembali sesuai dengan janji yang telah disepakati dengan responden.

Kuesioner yang disebarkan berjumlah 64 kuesioner dan yang dikembalikan sejumlah 60 kuesioner, dengan tingkat respon rate $93,75 \%$. Sebanyak 8 kuesioner tidak dapat diikutsertakan dalam analisis karena pengisian yang tidak lengkap. Jumlah data yang bisa diolah adalah sebanyak 52 kuseioner atau sebesar 81,25\%. Secara lengkap data disajikan dalam tabel 1.

\section{Hasil Uji Kualitas Data}

Menurut Hair, et al (1998) kualitas data digunakan untuk mengetahui konsistensi dan akurasi data yang dikumpulkan dari penggunaan instrumen.

\section{Uji Reliabilitas}

Menurut Sekaran (2000), berdasarkan nilai Alpha, reliabilitas dapat dikategorikan berikut ini. Nilai Alpha antara 0,8 sampai dengan 1,0 dikategorikan reliabilitas baik, nilai Alpha antara 0,60 sampai dengan 0,79 dikategorikan reliabilitas diterima dan nilai Alpha kurang dari 0,60 dikategorikan reliabilitas kurang baik.Hasil uji reliabilitas variabel penelitian ini dapat dilihat pada tabel 2. Hasil pengujian reliabilitas untuk semua butir jawaban kuesioner masing-masing variabel dalam penelitian menunjukkan bahwa nilai Alpha terletak di antara 0,60 sampai dengan 0,79 yang berarti reliabilitas diterima.

\section{Uji Validitas}

Dari sejumlah 31 pertanyaan yang dikelompokkan sesuai dengan variabel yang akan diuji yaitu variabel SDM terdapat 6 item 
pertanyaan, variabel $\mathrm{P}$ terdapat 5 pertanyaan dan untuk variabel PP 15 item pertanyaan. Hasil pengujian validitas variabel independen dan dependen menunjukkan nilai koefisien korelasi antar item-item pertanyaan dengan total skor item-item pada tingkat signifikansi 0,01 (1\%). Hal ini menunjukkan bahwa semua instrumen mempunyai hubungan yang signifikan. Dengan demikian instrumen-instrumen tersebut dapat dinyatakan valid karena masing-masing butir pertanyaan memang mengukur instrumen yang di ukur.

\section{Deskriptif Statistik}

Deskripsi statistik variabel penelitian ditujukan untuk memberikan gambaran tentang tanggapan responden dapat dilihat pada tabel 3 . Tabel statistik deskriptif menunjukkan bahwa variabel keberhasilan penerapan akuntansi akrual diperoleh rata-rata 4,12 berarti bahwa responden menjawab pertanyaan dengan pendapat setuju, maka dapat disimpulkan bahwa keberhasilan penerapan akuntansi akrual oleh Pemkot Yogyakarta adalah cukup. Variabel kompetensi sumberdaya manusia diperoleh rata-rata 3,90 berarti bahwa responden mempunyai persepsi mengenai Kompetensi sumberdaya manusia terhadap keberhasilan penerapan akuntansi akrual adalah cukup. Variabel perangkat pendukung, diperoleh rata-rata 3,82 berarti bahwa responden mempunyai persepsi mengenai perangkat pendukung terhadap keberhasilan penerapan akuntansi akrual juga cukup.

\section{Hasil Analisis Data}

Berdasarkan hasil analisis data, menunjukkan bahwa:

1. Berdasarkan hasil uji regresi model 1, menunjukkan bahwa Nilai Sig untuk variabel kompetensi sumberdaya manusia sebesar 0,011 lebih kecil daripada alpha (5\% atau $0,05)$, yang berarti bahwa kompetensi sumberdaya manusia berpengaruh signifikan terhadap keberhasilan penerapan Akuntansi Akrual (PP No.71 Tahun 2010). ). Sumber daya manusia merupakan faktor yang penting bagi setiap usaha. Nilai dari sumberdaya manusia merupakan jumlah nilai dari suatu organisasi yang dapat di sebut sebagai Modal intelektual yang terdiri dari orang-orang dalam organisasi, kemampuan yang mereka miliki, dan menggunakanya dalam pekerjaan mereka. Hasil penelitian ini mendukung penelitian sebelumnya yang dilakukan oleh Oluseyi (2010).

2. Berdasarkan hasil uji regresi model 2 menunjukkan bahwa Nilai Sig untuk variabel SDM yang berhubungan dengan perangkat pendukung sebesar 0,293 lebih besar daripada alpha (5\% atau 0,05), yang berarti bahwa SDM yang berhubungan dengan perangkat pendukung tidak berpengaruh signifikan terhadap keberhasilan penerapan Akuntansi Akrual (PP No.71 Tahun 2010). Teknologi informasi yang menjadi suatu kebutuhan untuk mendukung kesuksesan penerapan standar akuntansi pemerintah berbasis full accrual penggunaannya belum optimal. Hasil penelitian ini mendukung penelitian sebelumnya yang dilakukan oleh Sulani (2009).

\section{KESIMPULAN DAN SARAN}

\section{Kesimpulan}

Berdasarkan hasil analisis data dan pengujian hipotesis, maka ditarik kesimpulan sebagai berikut:

1. Kompetensi sumberdaya manusia berpengaruh signifikan terhadap keberhasilan penerapan Akuntansi Akrual (PP No.71 Tahun 2010).

2. Kompetensi sumberdaya manusia yang berhubungan dengan Perangkat pendukung tidak berpengaruh signifikan terhadap 
keberhasilan penerapan Akuntansi Akrual (PP No.71 Tahun 2010).

\section{Saran}

Berdasarkan kesimpulan hasil penelitian diatas, maka saran untuk penelitian selanjutnya sebagai berikut:

1. Penelitian selanjutnya hendaknya menambahkan variabel-variabel lain yang mungkin berpengaruh terhadap keberhasilan penerapan akrual.

2. Penelitian ini dilakukan pada organisasi pemerintah yang tidak terbatas pada hanya satu kabupaten saja karena di Indonesia ada ratusan kabupaten/kota.

\section{DAFTAR PUSTAKA}

Hair JF., Anderson, R.E. Tatham, R.L. and Black W.C. 1998. Multivariate Data Analysis. 5 th Edition. New Jersey, Prentice Hall.

Mahsun, Moh. Firma S dan H. Andre P. 2012. Akuntansi Sektor Publik. Edisi ketiga. Yogyakarta: BPFE

Mahmudi. 2011. Akuntansi Sektor Publik. UII pres. Yogyakarta.

Oluseyi O, Adesina. 2010. A comparative study of the adoption of accrual accounting in government. $\mathrm{PhD}$ Thesis, Cardiff University.
Peraturan Pemerintah Nomor 24 Tahun 2005 tentang Standar Akuntansi Pemerintahan.

Peraturan Pemerintah Nomor 71 Tahun 2010 tentang Standar Akuntansi Pemerintahan.

Sulani A, Aldiani. 2009. .Faktor-Faktor Pendukung Keberhasilan penerapan Peraturan Pemerintah No.24 Tahun 2005 pada Pemerintah kabupaten Labuhan batu. UNSU.

Sekaran, Uma. 2000. Research Method for Business: A Skill Building Approach. Third Edition. New York: John Wiley \& Sons, Inc.

Steccolini, Ileana and Eugenio Annessi. 2003. Accrual Accounting in Italian Local Governments: Is it working?Can it work?. Tersedia di www.ssrn.com. Diakses pada 20 Mei 2014.

Roviyantie, Devi. 2012. Pengaruh Kompetensi Sumber Daya Manusia Dan Penerapan Sistem Akuntansi Keuangan Daerah terhadap Kualitas Laporan Keuangan Daerah (Survei pada Organisasi Perangkat Daerah (OPD) Kabupaten Tasikmalaya. http://journal.unsil.ac.id. 